\title{
Health ministry accepts liability in Japanese HIV-infected blood row
}

Tokyo. After more than six years of court battles, Japan's Ministry of Health and Welfare (MHW) last week finally accepted partial responsibility for failing to prevent the infection of thousands of Japanese haemophiliacs in the 1980s with HIV by contaminated blood products.

Last Friday (16 February), Naoto Kan, Japan's Minister of Health and Welfare, who has been pushing to resolve the blood product scandal since his appointment as minister last month, offered his "heartfelt apologies" directly to a large group of HIV-positive haemophiliacs and relatives of AIDS victims at a press conference at the ministry.

He added that, on behalf of the government, he "completely accepted" the views of Tokyo and Osaka district courts that "the government's delay in action magnified the damage". This apology and admission of

responsibility had been sought through court action by the haemophiliacs since 1989 , but finally came after hundreds of HIV-positive haemophiliacs and their supporters staged a three-day sit-in in tents outside the MHW in Tokyo last week.

Kan's address marks the first time that the government has clearly accepted any responsibility for the disaster, in which twofifths of Japan's 5,000 haemophiliacs were infected with HIV. The MHW took two years, from 1983 to 1985 , to approve blood products heat-treated to kill HIV and other viruses, and even after approval of these products in July 1985 it failed to ban products that had not been heat-treated. During this period, large numbers of haemophiliacs were infected with HIV (see diagram over).

The plaintiffs decided to stage a sit-in outside the ministry after five companies that distributed the contaminated blood

\section{Canadian inquiry points the finger}

Montreal. More than 300 potential allegations of misconduct, contained in documents filed in federal court as a result of a commission of inquiry into Canada's contaminated blood scandal and made public last week, appear to form a searing indictment of the country's blood distribution system.

The allegations, which represent the provisional conclusions of the inquiry, headed by $\mathrm{Mr}$ Justice Horace Krever, point not just to possible neglect of duty among official bodies but sometimes to apparently deliberate malfeasance.

The Bureau of Biologics, for example, the body responsible for regulating and monitoring blood safety, is said by Krever to have failed to inform physicians and consumers of the risks of potentially contaminated blood products until 1988 - several years after such risks had been established. Indeed, it is also charged with approving potentially hazardous products as late as 1994.

According to Krever, another federal agency, the Laboratory Centre for Disease Control, may have distributed inaccurate and misleading information about AIDS while trying to reassure the public, according to court documents. The National Advisory Committee on AIDS, consisting of federally appointed scientists, purportedly allowed the public to be told in a pamphlet that the risk of contracting HIV from a blood transfusion was only about two in a million - whereas in late 1985 it was already known to be as high as one in 166 for major surgery.

Some of Krever's most serious allegations are aimed at the Canadian Blood Committee. The committee is made up senior federal and provincial health officials responsible for funding and overseeing the blood system, and Krever claims in his provisional conclusions that the committee was incapable of fulfilling its objectives, as its members had no pertinent expertise, no autonomy and insufficient resources.

The panel allegedly based the allocation of both money and plasma partly on political considerations, such as regional economic development needs, and devoted its resources to inadequate fractionation techniques, on which almost C $\$ 700$ million (US $\$ 510$ million) was wasted. The committee is also alleged to have hidden shortcomings in the regulation of blood products.

All the groups against which the allegations have been made have been given a chance to respond before Krever delivers his final verdict - though this is now expected to be delayed in the light of legal challenges to the procedure that Krever has adopted (see Nature 379, 479; 1996).

David Spurgeon

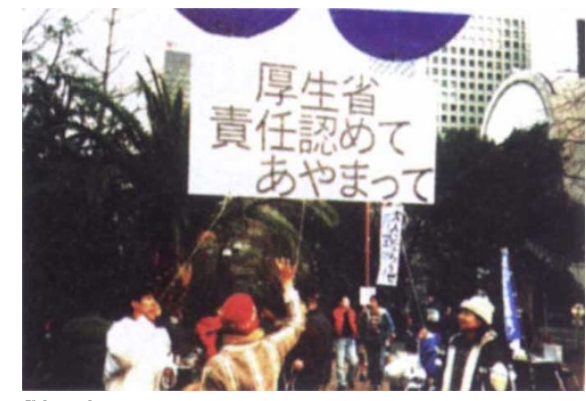

Blood pressure: demonstrators mount a sit-in to force the government to admit mistakes.

coagulants - as well as the government, which had approved their use - refused to admit responsibility for allowing the disaster to spread. This was even after the Tokyo and Osaka courts urged them last October to pay large amounts of compensation to the victims in an out-of-court settlement.

The HIV-positive haemophiliacs - concealed within open tents in order to protect their privacy - were joined by large numbers of mostly youthful supporters, who held banners urging the ministry to admit its fault and apologize to the victims. Addresses to the crowd by victims and their families expressed sorrow at their loss, and anger at the government's continued recalcitrance.

Both the demonstration and Kan's apology follow the recent 'discovery' of files in the ministry building showing that health officials were aware that blood products were a possible route of HIV transmission in July 1983 (see Nature 379, 572; 1996).

Tetsu Noma, who is acting for the plaintiffs in the Tokyo court case, says that the discovery of the files, taken with Kan's apology, will have a "large effect" on the negotiations between the plaintiffs and the government, as they clearly establish the government's liability.

The biggest remaining barrier to a settlement, says Noma, is the unwillingness of two non-Japanese companies implicated in the scandal, Baxter Ltd and Bayer Yakuhin Ltd, to pay their share of the settlement proposed by the Tokyo and Osaka courts last October. The proposal suggested that the parties reach an out-of-court settlement in which each victim would be paid $¥ 45$ million (US $\$ 420,000$ ), with 60 per cent of the cost to be met by the companies and the remainder by the government (see Nature 377, 467;1995).

Negotiations over the settlement have progressed only slowly, as a political resolution is needed to meet the demands, says Noma. He claims that the government's budget is a key factor in any decision, as 